FINANSIA: Jurnal Akuntansi dan Perbankan Syariah

P-ISSN: 2621-4636; E-ISSN: 2621-4644 Volume 02, Nomor 01, Januari-Juni 2019

Website: www.febi.metrouniv.ac.id;

E-mail: jurnalfinansia@gmail.com

\title{
Corporate Governance sebagai Moderating Variable dalam Pengaruh Kualitas Laba terhadap Nilai Perusahaan
}

\author{
Esty Apridasari \\ Fakultas Ekonomi dan Bisnis Islam IAIN Metro \\ estyaprida@gmail.com
}

\begin{abstract}
The separation of ownership between the principal and agent in a company could cause a conflict of interest where both parties try to maximize their own interests. The mechanism of corporate governance is expected to minimize this conflict of interest. This study examines the corporate governance variables as moderating variable in the influence of earnings quality on firm value. The population of this research is 66 manufacturing companies which are listed on the Indonesia Stock Exchange in 2014-2016 and 175 observations. Coorporate governance is measured by manajemen ownership, institutional ownership, independent commissioners, and the audit committee. Data analysis is using multiple regression. The results show that mangerial ownership has not been proven as moderating variable in the influence of earnings quality on firm value. Institutional ownership, independent board of commissioners, and audit committee could moderate the influence of the earnings quality to firm value.
\end{abstract}

Keywords: Corporate Governance, Earning Quality, Firm Value.

\begin{abstract}
Abstrak : Pemisahan kepemilikan antara principal dan agen dalam suatu perusahaan dapat menyebabkan munculnya konflik kepentingan di mana masingmasing pihak berusaha untuk memaksimalkan kepentingannya masing-masing. Mekanisme corporate governance diharapkan dapat menurunkan konflik kepentingan ini. Penelitian ini menguji corporate governance sebagai moderating variable dalam pengaruh kualitas laba terhadap nilai perusahaan. Populasi dalam penelitian ini adalah sebanyak 66 perusahaan manufaktur pada Bursa Efek Indonesia periode 2014-2016 dengan 175 data. Corporate governance diukur dengan kepemilikan saham oleh manajemen, kepemilikan saham oleh institusi, dewan komisaris independen, dan komite audit. Analisis data yang digunakan adalah analisis regresi berganda. Hasil penelitian menunjukan bahwa kepemilikan saham oleh manajemen tidak terbukti sebagai moderating variable pada pengaruh kualitas laba terhadap nilai perusahaan. Kepemilikan saham oleh institusi, dewan komisaris independen, dan komite audit terbukti dapat berperan sebagai moderating variable dan memperkuat pengaruh kualitas laba terhadap nilai perusahaan.
\end{abstract}

Kata Kunci: Corporate Governance, Kualitas Laba, Nilai Perusahaan. 


\section{A. Latar Belakang}

Bagian pendahuluan terutama berisi: Konflik kepentingan dalam teori agensi timbul akibat adanya pemisahan kepemilikan antara principal dan agen. Konflik kepentingan muncul karena kedua pihak (principal dan agen) berusaha untuk memaksimalkan kepentingannya masing-masing. Agen atau manajemen selaku pengelola dalam sebuah organisasi/perusahaan cenderung memiliki informasi yang lebih banyak dibandingkan dengan principal. Hal inilah yang kemudian memicu terjadinya ketimpangan informasi yang memberikan kesempatan kepada manajemen melakukan suatu tindakan dengan berorientasi kepada laba dalam rangka mencapai kinerja tertentu.

Konflik kepentingan yang terjadi antara principal dan agen ini juga dapat meningkatkan prilaku oportunistik manajemen dalam melaporkan laba yang ada pada laporan keuangan sehingga kualitas laba dalam laporan keuangan yang ada menjadi diragukan. Menurunnya kualitas laba pada pelaporan keuangan ini akan mengakibatkan nilai perusahaan berkurang di masa depan. ${ }^{1}$

Salah satu cara yang dapat digunakan untuk mengatasi konflik kepentingan yang terjadi ini adalah dengan menerapkan mekanisme coorporate governance. Mekanisme corporate governance seperti komposisi internal dan eksternal diduga dapat meminimalisir konflik kepentingan yang terjadi. ${ }^{2}$

Teori agensi memberikan pandangan bahwa masalah keagenan dapat diminimumkan melalui pengawasan untuk menyamakan kepentingan antara principal dan agen diantaranya melalui peningkatkan kepemilikan saham oleh manajemen dan saham oleh institusi. Pengawasan oleh dewan komisaris independen, dan komposisi komite audit yang ada dalam suatu perusahaan/organisasi. ${ }^{3}$

Kepemilikan saham oleh manajemen dianggap dapat mengurangi konflik keagenan yang terjadi karena dengan adanya kepemilikan saham oleh manajemen, agar para manajer dapat selaras dalam bertindak dengan kepentingan principal karena manajer akan termotivasi untuk meningkatkan kinerjanya. ${ }^{4}$ Kepemilikan saham oleh institusi juga dianggap dapat mengurangi konflik keagaenan dan manipulasi laporan keuangan yang dapat menurunkan kualitas laba dalam suatu perusahaan. Jiambavo mengatakan bahwa discretionary absolute memiliki hubungan yang negatif dengan kepemilikan saham oleh institusi. ${ }^{5}$ Kepemilikan saham oleh manajemen dan saham oleh institusi juga diharapkan dapat berpengaruh pada perusahaan sehingga dapat pula mempengaruhi kinerja perusahaan tersebut untuk memenuhi tujuannya dan meningkatkan nilai perusahaan. ${ }^{6}$

${ }^{1}$ Herawaty, V, "Peran Praktek Corporate Governance Sebagai Moderating Variable dari Pengaruh Earnings Management Terhadap Nilai Perusahaan” dalam Jumal Akuntansi dan Keuangan, Vol. 10 (2), November, 2008, p. 98

${ }^{2}$ Barnhart, S. dan S. Rosentein, "Board Composition, Managerial Ownership and Firm Performance: An Empirical Analysis’ dalam The Financial Review, November, 1998, p. 33-34.

${ }^{3}$ Herawaty, V, "Peran Praktek, p. 99

${ }^{4}$ Siallagan, H. dan M. Machfoedz, "Mekanisme Corporate Governance, Kualitas Laba dan Nilai Perusahaan" dalam Simposium Nasional Akuntansi IX Padang, 2006, p.56

5 Jiambavo, J, "Discussion of Causes and Consequenses of Earnings Manipulation" dalam Contemporary Accounting Research, Vol 13, Spring, 1996, p. 40.

${ }^{6}$ Wahyudi, U. dan H.P. Pawestri, "Implikasi Strktur Kepemilikan Terhadap Nilai Perusahaan: Dengan Keputusan Keuangan Sebagai Variabel Intervening" dalam Simposium Nasional Akuntansi (SNA) IX Padang., 2006, p.10 
Selain itu, komposisi dewan komisaris independen juga komposisi komite audit juga dianggap berpengaruh terhadap kualitas laporan keuangan perusahaan. Dengan perannya dalam mengawasi jalannya perusahaan, dewan komisaris diharapkan bisa menekan manipulasi laporan keuangan sehingga laporan keuangan yang dihasilkan bisa

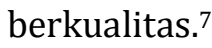

Komite audit juga diharapkan dapat mengurangi manajemen laba dengan audit yang dilakukan dan pengawasan pengendalian internal. ${ }^{8}$ Menurut Klein, ada pengaruh anatara komite audit dengan kandungan akrual diskresioner yang dilaporkan. ${ }^{9}$

Secara umum, komponen mekanisme corporate governance yang meliputi komposisi saham manajemen da institusi, dewan komisaris indenpenden dan komite audit mempunya keterkaitan yang siginfikan dengan kualitas laba yang dilaporkan. Penelitian ini melihat apakah mekanisme coorporate governance dapat memperkuat pengaruh dari kualitas laba terhadap nilai perusahaan pada perusahaan manufaktur yang tercatat di Bursa Efek Indonesia untuk periode waktu 2014-2016.

\section{Pengembangan Hipotesis}

Corporate governance merupakan seperangkat aturan yang di dalamnya diatur keterkaitan antar pihak manajemen dan pemilik, investor, pemerintah, karyawan dan para stakeholder.10 Mekanisme coorporate governance ini terdiri dari komposisi kepemilikan saham oleh manajemen dan saham oleh institusi serta proporsi dewan komisaris independen dan komite audit.

Dalam mekanisme corporate governance, masalah keagenan dapat diminimumkan melalui mekanisme pengawasan untuk menyamakan kepentingan antara principal dan agen diantaranya melalui peningkatkan kepemilikan saham oleh manajemen dan saham oleh institusi. Hal ini disebabkan karena adanya asumsi bahwa dengan meningkatnya kepemilikan saham oleh manajemen, maka manajemen akan merasa ikut memilki perusahan tersebut sehingga hal ini akan menurunkan manipulasi laporan keuangan perusahaan dan akan meningkatkan kualitas laporan keuangan perusahaan tersebut.

Beberapa penelitian menyatakan bahwa ada hubungan yang positif antara kepemilikan saham oleh manajemen dan nilai perusahaan. Menurut Boediono, kepemilikan saham oleh manajemen dapat meningkatkan kualitas laba pada laporan keuangan. ${ }^{11}$

Kepemilikan saham oleh institusi juga dianggap sebagai hal yang dapat meminimalisir manipulasi laporan keuangan. Hal tersebut didasarkan pada logika bahwa semakin besar kepemilikan saham yang dimiliki oleh institusi, maka akan meningkatkan pengawasan yang dilakukan oleh institusi tersebut terhadap kinerja manajemen. Dengan adanya pengawasan yang optimal, maka diharapkan kualitas laba perusahaan dan nilai

${ }^{7}$ Boediono, G.S.B, "Kualitas Laba: Studi Pengaruh Mekanisme Corporate Governance dan Dampak Manajemen Laba dengan Menggunakan Analisis Jalur" dalam Simposium Nasional Akuntansi (SNA) VIII Solo, 2005, p.176

8 Siallagan, H. dan M. Machfoedz, Mekanisme Corporate Governance, p.56

${ }^{9}$ Klein, A, "Audit Committee, Board of Directors characteristic and Earning management" dalam Journal of Accounting and Economics, Vol. 33, 2002, p. 376.

${ }^{10}$ Forum for Corporate Governance in Indonesia, "Peranan Dewan Komisaris dan Komite Audit dalam Pelaksanaan Corporate Governance" dalam Seri Tata Kelola Perusabaan, Jilid II, 2001, http://www.fcgi.org.id

${ }^{11}$ Boediono, G.S.B, Kualitas Laba, p.176 
perusahaan juga akan semakin meningkat. Kepemilikan saham oleh manajemen dan institusi merupakan komponen coorporate governance yang dapat menurunkan konflik kepentingan yang teimbul akibat adanya teori agensi.

Dewan komisaris independen juga merupakan salah satu mekanisme yang dianggap bisa meminmalisir konflik kepentingan dalam teori agensi. Hal ini berdasarkan asumsi bahwa komisaris independen dapat mengawasi kebijakan manajemen dan membantu melaksanakan fungsi monitoring. Adanya dewan komisaris independen juga dapat mengoptimalkan pengawasan terhadap manajemen untuk mencegah terjadinya kecurangan laporan keuangan. Hal ini tentunya akan meningkatkan kualitas laba dan nilai perusahaan.

Hasil penelitian Xie, Davidson, dan Dadalt, menyatakan bahwa dewan komisaris independen berpengaruh menurunkan manajemen laba, semkin banyak pertemua yang dilakukan oleh dewan komisaris independen, maka tingkat akrul perusahaan akan semikin sedikit. 12

Komite audit adalah suatu komite bentukan dewan komisaris yang tugasnya adalah mengawasi jalannya suatu perusahaan. Komite audit dibentuk dengan tujuan dapat memberikan opini terkait dengan masalah dalam hal keuangan, pengendalian intern dan akuntansi. merupakan komite yang dibentuk oleh dewan komisaris untuk melakukan tugas pengawasan pengelolaan perusahaan. Komite audit ini dapat bisa meminimalisir terjadinya manajemen laba dengan melakukan pengawasan pada laporan keuangan. Dengan adanya pengawasan yang optimal terhadap laporan keuangan, diharapkan laba yang dihasilkan akan lebih berkualitas.

Hasil penelitian Mayangsari tentang pengaruh komite audit terhadap integritas laporan keuangan. Menunjukkan bahwa komite audit memiliki hubungan yang negaftif terhadap integritas laporan keuangan. ${ }^{13}$ Menurut Suaryana perusahaan yang membentuk komite audit memiliki kualitas laba yang lebih baik daripada perusahaan yang tidak membentuk komite audit. ${ }^{14}$

Berdasarkan uraian tersebut, maka hipotesis yang akan diuji dalam penelitian ini adalah sebagai berikut:

$\mathrm{Ha}_{1}$ : Kepemilikan saham oleh manajemen memperkuat pengaruh kualitas laba terhadap nilai perusahaan

$\mathrm{Ha}_{2}$ : Kepemilikan institusi memperkuat pengaruh kualitas laba terhadap nilai perusahaan

$\mathrm{Ha}_{3}$ : Dewan komisaris independen memperkuat pengaruh kualitas laba terhadap nilai perusahaan

$\mathrm{Ha}_{4}$ : Komite Audit memperkuat pengaruh kualitas laba terhadap nilai perusahaan

\section{Metode Penelitian}

Populasi pada penelitian ini adalah perusahaan manufaktur yang tercatat di Bursa Efek Indonesia dalam rentang waktu 2014 sampai dengan 2016. Pemilihan sampel dengan menggunakan metode purposive sampling dengan kriteria yang telah ditetapkan

${ }^{12 X i e, ~ B . ; ~ W . N . ~ D a v i d s o n ; ~ d a n ~ P e t e r ~ J . ~ D a d a l t, ~ " E a r n i n g ~ M a n a g e m e n t ~ a n d ~ C o r p o r a t e ~ G o v e r n a n c e: ~}$ The Roles Of The Board and The Audit Committee" dalam Journal of Corporate Finance, Vol. 9, 2003, p. 297.

${ }^{13}$ Mayangsari, S, “Analisis Pengaruh Independensi, Kualitas Audit, serta Mekanisme Corporate Governance Terhadap Integritas Laporan Keuangan” dalam Simposium Nasional Akuntansi VI, 2003, p. 1256.

${ }^{14}$ Suaryana, A, "Pengaruh Komite Audit Terhadap Kualitas Laba" dalam Simposium Nasional Akuntasi VIII. Solo, 2005, p. 150. 
diantaranya memiliki data yang lengkap terkait variabel yang akan diteliti. Dengan jumlah sampel sebanyak 66 perusahaan.

Penelitian ini merupakan penelitian lanjutan, dimana sebelumnya peneliti meneliti tentang pengaruh kualitas laba terhadap nilai perusahaan. Karena itu variabel dependen yang independen yang digunakan sama dengan penelitian sebelumnya yaitu kualitas laba sebagai variabel dependen yang diukur dengan ERC (Earnings Response Cooeficient) dan nilai perusahaan sebagai variabel independen yang diukur dengan PBV (Price Book Value).

Moderating variabel dalam penelitain yaitu mekanisme corporate governance, yang terdiri dari:

a. Kepemilikan saham oleh manajemen

Yang dikukur dengan perbandingan jumlah saham milik manajemen dan jumlah modal saham perusahaan.

$K M=\frac{\sum \text { saham manajemen }}{\sum \text { modal saham perusahan }} \times 100 \%$

b. Kepemilikan Saham oleh institusi

Diukur berdasarkan perbandingan jumlah saham milik insitusi dengan modah salah perusahaan.

$K I=\frac{\sum \text { saham institusional }}{\sum \text { modal saham perusahan }} \times 100 \%$

c. Dewan Komisaris Independen

Dewan Komisaris independen menggunakan indikator jumlah anggota dewan komisaris independen dibandingkan dengan jumlah keseluruhan anggota dewan komisaris yang dimilki oleh perusahaan.

$D K=\frac{\sum \text { anggota komisaris independen }}{\sum \text { anggota dewan komisaris }} \times 100 \%$

d. Komite audit

Komite audit dalam penelitian ini diukur dengan menggunakan persentase jumlah anggota komite audit yang berasal dari luar perusahaan terhadap seluruh jumlah anggota komite audit perusahaan. ${ }^{15}$

$$
K A=\frac{\sum \text { anggota } \text { komite audit dari luar }}{\sum \text { seluruh anggota komite audit }} \times 100 \%
$$

Teknik Analisis Data

Pengujian hipotesis dalam peelitian ini menggunakan analisis regresi berganda, dengan persamaan regresi:

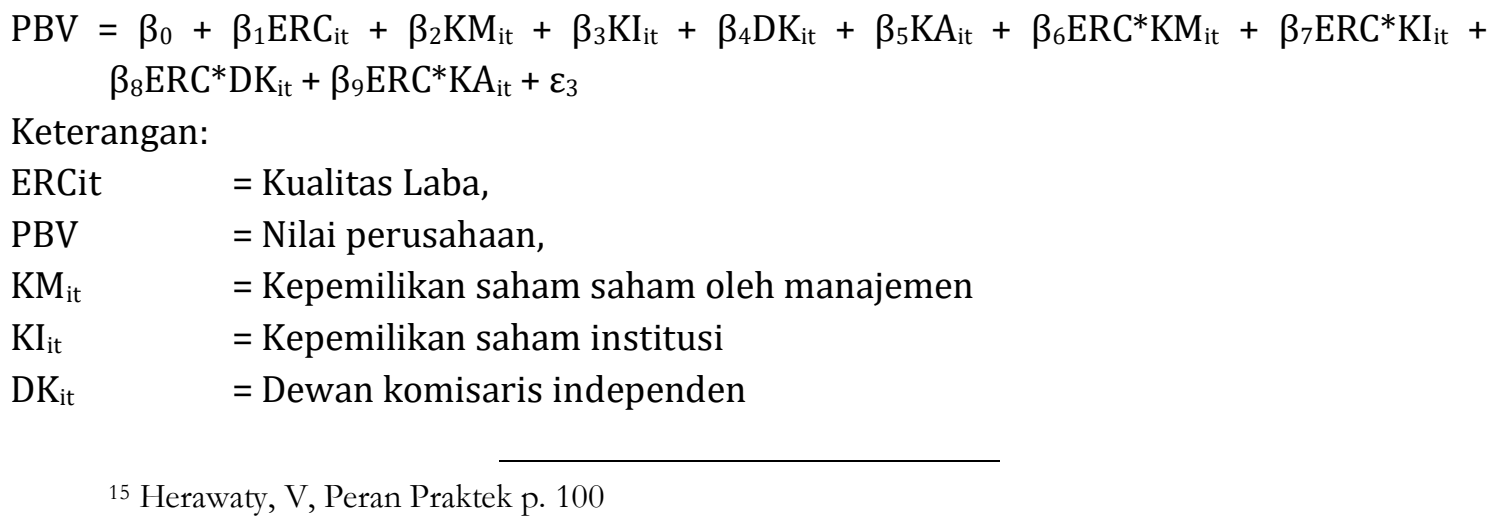




$$
\begin{aligned}
& \mathrm{KA}_{\mathrm{it}} \quad=\text { Komite audit } \\
& \varepsilon \quad=\text { Error term. }
\end{aligned}
$$

\section{B. Hasil dan Pembahasan}

Hasil statistik deskriptif data penelitian komponen coorporate governance yang meliputi kepemilikan saham manajemen, kepemilikan saham institusi, dewan komisaris independen, dan komite audit dapat dilihat dalam tabel berikut:

Tabel 1

Hasil Statistik Deskriptif

\begin{tabular}{|l|c|c|c|c|}
\hline \multicolumn{1}{|c|}{ Variabel } & Min & Max & Mean & $\begin{array}{c}\text { Std. } \\
\text { Deviation }\end{array}$ \\
\hline Kepemilikan saham manajemen & 0,00 & 0,70 & 0,0354 & 0,10709 \\
\hline Kepemilikan saham institusi & 0,22 & 0,98 & 0,6986 & 0,16610 \\
\hline Dewan komisaris independen & 0,00 & 0,67 & 0,3844 & 0,10382 \\
\hline Komite audit & 0,50 & 1,00 & 0,7839 & 0,16201 \\
\hline
\end{tabular}

Sumber: Data sekunder diolah, 2018

Dari tabel di atas, dapat dilihat, untuk kepemilikan saham oleh manajemen memiliki nilai minimal 0 dan nilai maksimal 0,70. Artinya, terdapat perusahaan yang tidak mempunyai saham yang dimiliki oleh manajemen dan nilai tertinggi kepemilikan saham oleh manajemen sebesar 70 persen. Pada kepemilikan saham oleh institusi, nilai minimal 0,22 dan nilai maksimal 0,98. Artinya, nilai terkecil kepemilikan saham oleh institusi sebesar 22 persen dan nilai tertinggi kepemilikan saham oleh institusi sebesar 98 persen. Nilai dewan komisaris independen memiliki nilai minimal 0 dan nilai maksimal 0,67. Artinya, terdapat perusahaan yang tidak mempunyai dewan komisaris independen dan persentase nilai dewan komisaris independen tertinggi sebesar 67 persen. Sedangkan untuk nilai komite audit, nilai minimum sebesar 50 persen dan nilai maksimal sebesar 100 persen.

Untuk hasil analisis regresi berganda, dapat terlihat dari tabel di bawah ini:

Tabel 2

\begin{tabular}{|c|c|c|c|}
\hline Variabel & Coefficient & $t_{\text {hitung }}$ & $\rho_{\text {Value }}$ \\
\hline (Constant) & $-0,497$ & $-4,601$ & 0,000 \\
\hline Earnings Response Coefficient (ERC) & 5,646 & 5,947 & 0,000 \\
\hline Kepemilikan Saham oleh manajemen (KM) & $-0,215$ & $-0,408$ & 0,684 \\
\hline Kepemilikan Saham oleh institusi (KI) & 0,983 & 3,242 & 0,001 \\
\hline Dewan Komisaris Independen (DK) & 0,788 & 2,182 & 0,031 \\
\hline Komite Audit (KA) & 2,020 & 6,084 & 0,000 \\
\hline ERC*KM & $-1,083$ & $-0,980$ & 0,329 \\
\hline ERC*KI & 1,981 & 2,447 & 0,015 \\
\hline ERC*DK & 1,468 & 1,904 & 0,059 \\
\hline ERC*KA & 3,864 & 4,575 & 0,000 \\
\hline $\begin{array}{l}\text { Adj } R^{2}=0,489 \\
F_{\text {hitung }}=19,474 \\
\text { Sig }=0,000\end{array}$ & & & \\
\hline
\end{tabular}

Hasil Pengujian Regresi 


Variabel Dependen: Nilai Perusahaan

Sumber: Data sekunder diolah, 2018

Berdasarkan hasil perhitungan di atas, untuk kepemilikan saham oleh manajemen mempunyai probability value sebesar 0,329 yang mana nilai ini lebih besar dari tingkat signifikansi sebesar 0,05 $\mathbf{H}_{\mathbf{a} 1}$ ditolak. Hal ini menunjukan bahwa variabel kepemilikan saham oleh manajemen tidak terbukti berperan sebagai moderating variabel dalam hubungan antara kualitas laba dan nilai perusahaan. Kepemilikan saham oleh institusi memiliki probability value 0,015 yang mana nilai tersebut berada di bawah nilai signifikansi sebesar 0,05 sehingga untuk tingkat probability $5 \% \mathbf{H}_{\mathbf{a} 2}$ diterima. Artinya pada variabel ini merupakan variabel yang dapat memperkuat hubungan antara kualitas laba dan nilai perusahaan serta terbukti berperan sebagai moderating variabel.

Komisaris independen memiliki probability value 0,059 lebih besar dari 0,05 sehingga untuk tingkat probability $5 \%$ tidak signifikan. Artinya pada tingkat signifikansi 5\% kepemilikan komisaris independen bukan merupakan moderating variabel dan tidak mempekuat hubungan antara kualitas laba dan nilai perusahaan. Namun, variabel kepemilikan saham oleh institusi ini signifikan pada tingkat $10 \%$ sehingga pada tingkat probability $10 \%, \mathbf{H}_{\mathbf{a} 3}$ diterima. Komite audit memiliki besaran probability value 0,000 yang berarti bahwa $\mathbf{H}_{\mathbf{a} 4}$ diterima. Artinya, komite audit terbukti memperkuat hubungan antara kualitas laba dan nilai perusahaan serta memiliki peran sebagai moderating variabel pada perusahaan manufaktur di Bursa Efek Indonesia.

\section{Pembahasan}

Hasil regresi menunjukan bahwa untuk moderating variabel kepemilikan saham oleh manajemen memiliki probability value 0,329 dengan parameter koefisien negatif. Nilai ini lebih besar dari 0,05 sehingga $\mathbf{H}_{\mathbf{a} 1}$ ditolak. Kepemilikan saham oleh manajemen tidak terbukti memiliki peran sebagai moderating variabel dan tidak memperkuat hubungan kualitas laba dan nilai perusahaan. Hasil penelitian ini bertentangan dengan yang diprediksi teori bahwa adanya kepemilikan saham oleh manajemen dalam suatu perusahaan akan menurunkan tingkat oportunistic manajemen karena manajemen akan merasa ikut memiliki perusahaan sehingga kualitas labanya akan meningkat.

Parameter koefisien negatif menunjukkan bahwa hasil penelitian ini mendukung penelitian yang menunjukkan terdapat hubungan berbanding terbalik antara tingkat saham yang dimiliki oleh manajemen dengan nilai perusahaan. Hasil ini memperlihatkan bahwa ketika jumlah kepemilikan saham oleh manajemen berada dalam tingkatan yang kecil, maka hal ini dapat mengurangi masalah keagenan karena efisiensi hak kontrol yang dilakukan oleh manajemen. Tetapi ketika kepemilikan sahamnya cukup besar, maka manajemen akan merasa memiliki hak kontrol berlebihan sehingga dapat memicu munculnya tindakan yang dapat menguntungkan dirinya sendiri tetapi dapat merugikan stakeholder lainnya.

Hasil penelitian yang tidak signifikan menunjukan bahwa tidak dalam pengaruh kualitas laba dan nilai perusahaan, variabel kepemilikan saham oleh manajemen tidak terbukti dapat memperkuat hubungan tersebut dan tidak berperan sebagai moderating variable. Hal ini dapat disebabkan oleh beberapa faktor, diantaranya masih kecilnya tingkat kepemilikan saham oleh manajemen yang terdapat di Indonesia sehingga tidak 
terlalu memiliki pengaruh terhadap kualitas laba dan nilai perusahaan. Dalam penelitian ini jumlah kepemilikan saham oleh manajemen rata-rata hanya sebesar 3,54\%.

Moderating variabel kepemilikan saham oleh institusi memiliki probability value 0,015. Tingkat signifikansi ini lebih kecil dari 0,05 sehingga $\mathbf{H}_{\mathbf{a} 2}$ diterima. Hal ini menunjukan bahwa kepemilikan saham oleh institusi terbukti dapat memperkuat pengaruh kualitas laba terhadap nilai perusahaan dan juga berperan sebagai moderating variabel dalam kualitas laba terhadap nilai perusahaan. Ini menunjukan bahwa yang lebih berperan dalam mengatasi konflik agensi dan dapat memperkuat pengaruh kualitas laba terhadap nilai perusahaan adalah tingkat kepemilikan saham oleh kelompok dibandingkan kepemilikan saham secara individu.

Hasil pengujian untuk moderating variabel dewan komisaris independen dan komite audit menunjukkan bahwa masing-masing memiliki tingkat signifikansi 0,059 dan 0,000. Probability value untuk variabel komisaris independen lebih besar dari 0,05 sehingga komisaris independen tidak berperan sebagai moderating variabel pada tingkat kepercayaan 5\%. Namun variabel komisaris independen ini signifikan pada tingkat $10 \%$. Hal ini menunjukkan bahwa pada tingkat 10\%, variabel komiaris independen berperan sebagai moderating variabel dan terbukti memperkuat pengaruh kualitas laba terhadap nilai perusahaan.

Untuk komite audit, probability value lebih kecil dari 0,05 sehingga $\mathbf{H a}_{4}$ diterima. Hal ini menunjukkan bahwa proporsi dewan komisaris independen dan komite audit yang diukur dengan persentase anggota komite audit yang berasal dari luar perusahan, akan memperkuat pengaruh kualitas laba terhadap nilai perusahaan. Semakin tinggi proporsi dewan komisaris independen dan komite audit yang berasal dari luar perusahaan, maka akan semakin memperkuat pengaruh kualitas laba terhadap nilai perusahaan. Hasil ini sesuai dengan yang diprediksi teori bahwa semakin tinggi jumlah dewan komisaris independen dan komite audit, maka akan mengurangi sifat opportunistic manajemen dengan cara mengawasi laporan keuangan dan melakukan pengawasan pada audit eksternal sehingga akan meningkatkan kualitas laba suatu perusahaan. merupakan bagian utama artikel hasil penelitian dan biasanya merupakan bagian terpanjang dari suatu artikel. Hasil penelitian yang disajikan dalam bagian ini adalah hasil "bersih". Pada sub judul ini memuat bagian-bagian rinci dalam bentuk sub topik yang berkaitan langsung dengan fokus penelitian. Pada jurnal ini tidak ada sub judul "hasil penelitian", tetapi sub judul berupa topik dan pembahasan. Jadi, penulis bebas membuat sub judul sesuai temuan penelitiannya.

\section{Kesimpulan}

Dari hasil penelitian dapat disimpulkan bahwa dari beberapa indikator yang digunakan dalam pengukuran mekanisme coorporate governance, yang berperan sebagai moderating variable dan terbukti memperkuat pengaruh kualitas laba terhadap nilai perusahaan adalah kepemilikan saham oleh institusi, dewan komisaris independen, dan komite audit. Sedangkan variabel kepemilikan saham oleh manajemen tidak terbukti berperan sebagai moderating variable dan tidak terbukti memperkuat pengaruh kualitas laba terhadap nilai perusahaan. 


\section{Daftar Pustaka}

Bao, B. dan D. Bao, Income Smoothing, Earnings Quality and Firm Valuation, Journal of Business, Finance \& Accounting, Vol. 31 (9) \& (10), 2004.

Barnhart, S. dan S. Rosentein. Board Composition, Managerial Ownership and Firm Performance: An Empirical Analysis. The Financial Review, November, 1998

Beiner, S.; W. Drobetz; M.M. Schmid; dan H. Zimmermann. An Integrated Framework of Corporate Governance and Firm Valuation. Working paper. http://papers.ssrn.com/sol3/papers.cfm?abstract id=489322. 2003

Boediono, G.S.B. Kualitas Laba: Studi Pengaruh Mekanisme Corporate Governance dan Dampak Manajemen Laba dengan Menggunakan Analisis Jalur. Simposium Nasional Akuntansi (SNA) VIII Solo, 2005

Faizal. Analisis Agency Cost, Struktur Kepemilikan, dan Mekanisme Corporate Governance. Jurnal Riset Akuntansi Indonesia, Vol.8 (2), 2005.

Forum for Corporate Governance in Indonesia. Peranan Dewan Komisaris dan Komite Audit dalam Pelaksanaan Corporate Governance. Seri Tata Kelola Perusahaan, Jilid II. http://www.fcgi.org.id, 2001

Ghozali, Imam. Aplikasi Analisis Multivariate dengan Program SPSS. (Semarang: Badan Penerbit Universitas Diponegoro, 2006)

Herawaty, V. Peran Praktek Corporate Governance Sebagai Moderating Variable dari Pengaruh Earnings Management Terhadap Nilai Perusahaan. Jurnal Akuntansi dan Keuangan, Vol. 10 (2), November, 2008.

Jiambavo, J. Discussion of Causes and Consequenses of Earnings Manipulation. Contemporary Accounting Research, Vol 13, Spring, 1996.

Klein, A, Audit Committee, Board of Directors characteristic and Earning management. Journal of Accounting and Economics, Vol. 33, 2002.

Komite Nasional Kebijakan Governance (KNKG). Pedoman Tentang Komisaris Independen. http://www.governance-indonesia.or.id/main.htm. 2004.

Mayangsari, S. Analisis Pengaruh Independensi, Kualitas Audit, serta Mekanisme Corporate Governance Terhadap Integritas Laporan Keuangan. Simposium Nasional Akuntansi VI, 2003.

Siallagan, H. dan M. Machfoedz. Mekanisme Corporate Governance, Kualitas Laba dan Nilai Perusahaan. Simposium Nasional Akuntansi IX Padang, 2006.

Suaryana, A. Pengaruh Komite Audit Terhadap Kualitas Laba. Simposium Nasional Akuntasi VIII. Solo, 2005. 
Wahyudi, U. dan H.P. Pawestri. Implikasi Strktur Kepemilikan Terhadap Nilai Perusahaan: Dengan Keputusan Keuangan Sebagai Variabel Intervening. Simposium Nasional Akuntansi (SNA) IX Padang,2006.

Xie, B.; W.N. Davidson; dan Peter J. Dadalt. Earning Management and Corporate Governance: The Roles of The Board and The Audit Committee. Journal of Corporate Finance, Vol. 9. 2003. 